\title{
Environmental legal regulations in dealing with noise
}

\author{
http://dx.doi.org/10.12775/PYEL.2013.006
}

\begin{abstract}
In the Polish legislation, as well as in the EU legislation environmental protection against noise is based on actions aiming at preventing noise generation and reducing its level, where it is necessary, in order to fulfil the requirements specified by the law. Regulations concerning noise protection apply mainly to such economic branches as road transport, rail transport, and air transport. Legal measures, which contribute to the provision of the best acoustic condition of the environment, are: development of environmental protection programmes against noise, maintaining noise emissions limits, integrated permits or permits for noise emissions to the environment.

Acoustic maps, whose purpose is to separate the areas exposed to noise, are of high importance in the context of noise protection. In reality a map
\end{abstract}

\section{Uniwersytet w Białymstoku.}




\section{Anna Pieniak}

gives an estimate of the environmental impact, giving the answer to at least the following questions: what is the state of the environment; what are the crucial issues with regards to the environment; what are the effects for the environment related to the realization of the analysed actions; how to prevent the negative effects; what protective measures should be implemented ${ }^{1}$. Acoustic maps should contain a descriptive and a graphical part, and the data included could be used as a base for actions taken by public administration in the scope of noise protection.

The development of civilization has contributed not only to the improvement of quality of life but also had a negative impact on the environment, natural resources have been used excessively and without any major restrictions. Along with the economic development noise appeared, which is one of the main problems of the modern world to this day. In this paper basic information regarding environmental protection from noise governed by the Environmental Protection Act of 27 April 2001 is presented. Such issues as noise, noise level limits, noise emissions and pollution are discussed in detail. Moreover, the problem of the compliance of solutions adopted by the Polish legislator with the regulations of the European Union in this scope is discussed.

\section{Introduction}

Nowadays, one of the most serious factors having impact on the environment is noise. It has a negative influence both on humans as well as the environment. The noise accompanies a man in every place from their early age. It has been proved to have a harmful impact on health and quality of life. The harmful impact on a human body manifests itself among others in decrease of hearing, it influences nervous and immunological system, causes tiredness, orientation disorder, annoyance, and even aggression.

The main source of noise influencing acoustic climate is: traffic noise, industrial noise, and municipal noise.

1 M. Pchałek, Procedura strategicznych ocen planów i programów a ocena oddziatywania na środowisko przedsięwzięcia, [w:] B. Rakoczy, M. Pchałek (red.), Wybrane problemy prawa ochrony środowiska, Warszawa 2010, p. 53. 
Traffic noise is produced by road traffic, tram traffic, railway traffic and air traffic. It has been demonstrated that the main source of noise traffic is road traffic, which comes from means of transportation using different types of roads. It is caused by the following factors: car traffic volume (including speed, lack of continuity of traffic), technical conditions of vehicles (especially urban means of transportation), state and type of pavements, increasing number of heavy vehicles. It has been estimated that this type of noise accounts for $70-80 \%$ of the noise present in a city area.

Railway traffic noise comes from railway operations. This is a linear source, the most noticeable close to railway tracks, emitted by several single sources. Its level depends mostly on the following factors: traffic volume, the number of freight trains, speed and continuity of railway traffic, railway tracks location, technical conditions of rolling stock and railway tracks, a shape of land with a railway, as well as the distance between the first line of buildings and the railway track. Railway traffic and municipal rail traffic noise is a nuisance in large municipalities being traffic junctions.

Air traffic should be considered as traffic noise. Since 1950s a dynamic development of civil aviation has been observed, contributing to a considerable increase of noise emission to the environment. Thus, it has become more disturbing for humans. The main sources of air traffic noise are plane engines during take-off, landing or taxing. The traffic noise impact concerns not only areas of airports, but also much larger areas, often up to several square kilometres. The major noise risk areas are the ones located in the vicinity of airports and take-off and landing air corridors. Noise level depends of the type of a plane, number of take-offs and landings, and air traffic organization, which determines not only take-off procedures, but also waiting time for landing reflecting the number of loops above an airport and neighbourhood. Some airports accept and check in large cargo planes, which takes place beyond the passenger traffic period, thus at nights, early mornings or late evenings ${ }^{2}$.

Industrial noise is the second largest source impacting the environment. It is present at industrial plants areas, manufacturing plants and craftsman facilities. There are various factors emitting noise and they depend on equipment and industrial machines, technological processes, installations and transportation inside a plant. A specific feature of plants is a continuous

2 K. Dworak, Hatas środowiskowy a zdrowie, Wojewódzka Stacja SanitarnoEpidemiologiczna w Katowicach, Katowice 2005, p. 14. 
annoying sound. In Poland the most onerous plants in terms of noise are heat and power stations, food processing plants, wood industry, as well as construction sites ${ }^{3}$.

The next group of noise impacting human life quality is municipal noise. It is present mostly in agglomerations and is annoying for inhabitants. Municipal noise comes from different sources, active periodically or twenty-four hours a day. Such noise can be continuous, discontinuous, and impulsive, with constant or variable traffic volume ${ }^{4}$. The main source is socalled 'neighbourhood noise', the noise in buildings or around buildings, related to service and commercial activities. All events organized in an open space, such as concerts, festivals, sport events are also the sources of noise.

\section{Noise as a legal term in the field of environment protection legislation}

'Noise' has no binding definition applicable in different branches of science dealing with noise control issues. According to Z. Engel 'noise' means all unwanted, annoying or harmful vibrations of the elastic medium, impacting hearing or other senses and elements of human body through the air ${ }^{5}$. Commonly 'noise' is considered as sounds that are unpleasant or unwanted, troublesome or harmful to health, hindering or disabling the work or the rest. It is a derivative of humans' activities or their technical devices ${ }^{6}$. From the above it can be concluded that a human is a source, maker and recipient of the consequences caused by excessive noise emissions.

To sum up 'noise' can describe each unwanted sound, which causes negative effects on both humans and the surrounding environment. The level of negative effects depends among others on a sound level, its frequency, continuity or discontinuity, duration, as well as subjective human assessment. In a laboratory noise is measured in decibels $(\mathrm{dB})$. It should be

3 Z. Engel, W. M. Zawieska, Ochrona przed hatasem w środowisku - stan zagadnienia w roku przystapienia do Unii Europejskiej, Bezpieczeństwo Pracy 5/2004, p. 9-13.

4 K. Dworak, Hatas..., p. 8.

5 Z. Engel, Ochrona środowiska przed drganiami i hatasem, Warszawa 2001.

6 H. Kujawa-Łobaczewska, J. Goszczyński (red:), Klimat akustyczny województwa kujawsko-pomorskiego w badaniach WIOŚ, Bydgoszcz 2004, p. 14. 
stressed that the unit of sound level is phon, which corresponds to sound intensity with frequency of $1000 \mathrm{~Hz}$, and $1 \mathrm{~dB}(\mathrm{~A})^{7}$.

The legislative definition of 'noise' is given in article 3 point 5 of the Environment Protection Act of 27 April $2001^{8}$ (further referred to as the EPA), according to which whenever 'noise' is mentioned in the act - it refers to the sound with frequency between 16 and 16,000 Hz. The definition does not cover so called infrasounds (sounds below $16 \mathrm{~Hz}$ ) and ultrasounds (above 16,000 Hz), thus it applies only to the sounds audible by a human. According to J. Jarzmanski ${ }^{9}$, such a definition is confusing and not applicable, due to the fact that noise within the meaning of the Act can be at the same time an emission (article 3 point 4 of the EPA) and pollution (article 3 point 49 of the EPA).

The Directive 2002/49/WE of the European Parliament and of the Council relating to the assessment and management of environmental noise, includes a legal definition of 'noise' ${ }^{10}$. According to article $3 a$ 'noise in the environment' concerns unwanted and harmful sounds caused by a human activity in the open air, including noise emitted by means of transportation, road traffic, railway traffic, air traffic and noise coming from industrial areas. The scope of regulations includes places, which are particularly exposed to noise, for example built-up areas, schools and hospitals. However, it does not apply to the noise caused by domestic activities, neighbours, noise occurring in work places or in the means of transportation.

\section{Regulations related to the environment protection from noise}

In the European Union environmental protection regulations with regard to noise are issued based on article $100 \mathrm{a}$ and article 118 of the Treaty of Rome. The main objective of these documents is the unification of regulations

7 J. M. Massalski, J. Stadnicki, Legalne jednostki miar i state fizyczne, Warszawa 1999.

8 Journal of Laws of 2008, No 25, item 150 with amendments.

9 J. Jerzmański, Dział V. Ochrona przed hatasem, wprowadzenie, [w:]M. Górski, M. Pchałek, W. Radecki, J. Jerzmański, M. Bar, S. Urban, J. Jendrośka, Prawo ochrony środowiska. Komentarz, Warszawa 2011, p. 415.

10 OJ [2002] L 189/12. 
of member states with regard to obligatory requirements concerning safety, health and environmental protection, including protection from noise.

One of the main sources of the community legislation regarding noise control present in the environment is the Directive 2002/49/WE mentioned above. The aim of this directive is the reduction of noise coming from such sources as road rolling stock, railway rolling stock, planes, and devices used outdoors, industrial devices, as well as self-propelled machines and equipment. The directive is also a basis for development of common measures in this field, and the basis for undertaking activities aiming at preventing and controlling negative effects of noise. Moreover, the directive has introduced common noise indicators, assuming that $\mathrm{L}_{\mathrm{DEN}}$ indicates the overall assessment of noise annoyance, whereas $\mathrm{L}_{\mathrm{NIGHT}}$, the assessment of sleep disturbance. Protection from noise is one of the EU priorities. Achieving this priority will contribute to both high level of health and environmental protection.

Among the directives containing legal standards related to noise the following can be listed:

1. The Directive 98/37/EC of the European Parliament and of the Council of 22 June 1998 on the approximation of the laws of the Member States relating to machinery ${ }^{11}$;

2. The Directive 2000/14/EC of the European Parliament and of the Council of 8 May 2000 on the approximation of the laws of the Member States relating to noise emissions in the environment by equipment for use outdoors ${ }^{12}$;

3. The Directive 2003/10/EC of the European Parliament and of the Council of 6 February 2003 on the minimum health and safety requirements regarding the exposure of workers to the risks arising from physical agents (noise) ${ }^{13}$.

In Poland the EPA is the first legal act regulating basic principles of protection from noise. In this act there is a separate chapter dealing with this issue - Chapter V 'Protection from noise'. According to article 112 of the EPA, environmental protection from noise consists in the provision of the best possible acoustic state of the environment, especially maintaining
OJ [1998] L 207.
OJ [2000] L 162.
13 OJ [2003] L 42. 
noise levels below noise limits, or at least at limit levels; reduction of noise to at least noise limit values if they are exceeded.

Permissible noise levels in the environment, indicated in article 112 of the EPA are determined by the regulation issued by the Minister of the Environment in the agreement with the Minister of Health. The regulation of the Minister of the Environment of 14 June 2007 on permissible levels of noise in the environment ${ }^{14}$ introduces different noise levels in the environment depending on the type of noise sources, as well as the place of occurrence. Additionally, it should be noticed that noise levels are determined based on so-called noise indicators. This term was introduced into the EPA by the amendment of $2005^{15}$, implementing the Directive 2002/49/WE. In accordance with the above in the context of article 112a, noise indicators are noise parameters specified by the sound level A, which is given in decibels $(\mathrm{dB})$. In the discussed regulation the legislator divided noise indicators into two types. The first one is related to a long term policy of environment protection from noise, and it is specified as $\mathrm{L}_{\mathrm{Dwn}}, \mathrm{L}_{\mathrm{N}}$. It is particularly useful in the development of acoustic maps and programs of environment protection from noise. The second type of indicators is used to determine and control conditions of the environmental use, particularly by issuing a decision on acceptable noise levels. This indicator is expressed by the equivalent sound level $\mathrm{A}$, which differs depending if it is a day-time or night-time $\left(\mathrm{L}_{\text {Aeq D }}, \mathrm{L}_{\text {Aeq } N}\right)$. At this point it is worth mentioning that presented noise indicators were used to determine noise level limits in the environment (article113 of the EPA).

Noise level limits are determined for the areas of specific destination: for residential buildings; for hospitals and social care; public buildings with temporary or constant presence of children and youth; for health resorts; for recreational areas; residential and service areas.

For each area mentioned above noise level limits have been additionally diversified with regard to a time of the day - day from 6 am to $6 \mathrm{pm}$, evening from $6 \mathrm{pm}$ to $10 \mathrm{pm}$, night from $10 \mathrm{pm}$ to $6 \mathrm{am}$; as well as with regard to the source of noise:

- Noise coming from roads or railways;

- Noise caused by take-off, landing, plane flying and power grids;

14 Journal of Laws, No 120, item 826.

15 The Act of 18 May 2005 on the act amendment - Environmental Protection Act and some other acts. 


\section{Anna Pieniak}

- Noise coming from other objects, installations and groups of noise sources ${ }^{16}$.

To determine noise level limits, besides the purpose of an area and a time of the day, the following factors can be also taken into account: variation of noise sources in time, frequency characteristics of the sound and content of acoustic impulses.

The purpose of an area is determined based on a local area development plan, which indicates the purpose category (mentioned in article 113 of the EPA) of the area. In the case of lack of a local area development plan the area is classified based on the actual land development and the use of the area as well as surrounding areas. However, not always the settlements of a local area development plan can solve all problems related to the nuisance of noise emissions. Therefore, in article 114 point 3 of the EPA it has been foreseen that in case of areas used for diversified purposes, such as for example health resorts, residential and service areas, hospitals etc., protection from noise consists in the application of technical solutions providing proper acoustic conditions in buildings. In practice such an obligation will be fulfilled at different stages of an investment process, such as issuing a decision on environmental conditions and a building permit ${ }^{17}$.

The regulation of the Minister of the Environment of 14 June 2007 divides noise level limits into two groups, which is consistent with article 112 of the EPA. The first group is used to determine level noise limits applicable in determination and controlling of the conditions of environmental use in relation to one day. It is divided into noise indicators coming from road and railways, other sources of noise and noise caused by aircraft operations and power grids. In this group levels of noise during the day are determined in the range from $50 \mathrm{~dB}$ to $65 \mathrm{~dB}$, during the night from $45 \mathrm{~dB}$ to $55 \mathrm{~dB}$. On 2 October 2012, the Minister of the Environment signed a regulation amending permissible noise levels in the environment, which increased levels of noise from roads or railways. According to the new regulation, the limits have been raised to $68 \mathrm{~dB}$ during the day and $60 \mathrm{~dB}$ at night.

The second group of noise level limits is specified by $\mathrm{L}_{\mathrm{DWN}}, \mathrm{L}_{\mathrm{N}}$ indicators and it is to be used for a long-term policy of protection from noise. Similarly to the first group, there is a differentiation made for noise caused by road and railways and noise caused by aircraft operations and power

16 J. Jendrośka, M. Bar, Prawo ochrony środowiska, podręcznik, Wrocław 2005, p. 876.

17 J. Stelmasiak (red.), Prawo ochrony środowiska, Warszawa 2009, p. 278-279. 
grids, assigning them to different groups of indicators. In this group, noise levels are determined in the range from $40 \mathrm{~dB}$ to $65 \mathrm{~dB}$ depending on the category of areas where noise occurs.

The method for calculation of $\mathrm{L}_{\mathrm{DWN}}$ indicators, according to article $112 \mathrm{~b}$ point 1 of the EPA has been established with the regulation of the Minister of the Environment of 10 November 2010 on the establishment of a noise indicator LDWN ${ }^{18}$.

In the context of the above mentioned Decree a noise indicator is estimated based on the following formula:

$$
L_{D W N}=10 \lg \left[\frac{12}{24} 10^{0,1 L_{D}}+\frac{4}{24} 10^{0,1\left(L_{W}+5\right)}+\frac{8}{24} 10^{0,1\left(L_{N}+10\right)}\right]
$$

where:

$\mathrm{L}_{\text {DWN }}$ - is long-term mean sound level A in decibels $(\mathrm{dB})$, determined during all days of the year, considering day time (from $6 \mathrm{am}$ to $6 \mathrm{pm}$ ), evening (from $6 \mathrm{pm}$ to $10 \mathrm{pm}$ ) and night time (from $10 \mathrm{pm}$ to $6 \mathrm{am}$ ).

$\mathbf{L}_{\mathbf{D}} \quad$ - is long-term mean sound level A in decibels $(\mathrm{dB})$, determined during all day times of the year (day time is considered from $6 \mathrm{am}$ to $6 \mathrm{pm}$ ).

$\mathbf{L}_{\mathrm{W}} \quad$ - is long-term mean sound level $\mathrm{A}$ in decibels $(\mathrm{dB})$, determined during all evenings of the year (evening is considered from $6 \mathrm{pm}$ to $10 \mathrm{pm}$ ).

$\mathbf{L}_{\mathbf{N}} \quad$-is long-term mean sound level $A$ in decibels $(\mathrm{dB})$, determined during all nights of the year (night is considered from $10 \mathrm{pm}$ to $6 \mathrm{am})$.

At the same time for a proper determination of $\mathrm{L}_{\mathrm{DWN}}$ it is also necessary to consider such factors as: the variation of noise sources during a year, the variability of atmospheric conditions and variability of factors influencing propagation of noise in the environment.

According to J. Jerzmanski the discussed regulation implements the provisions of the Directive 2002/49/WE, however, the references to the methods of estimation and assessment of noise levels are missing. In this context the attention should be paid to the provisions contained in two

18 Journal of Laws, No 215, item 1414. 


\section{Anna Pieniak}

other executive regulations for the EPA, which formulate reference methods for measurement and refer to the application of Polish standards $(\mathrm{PN})^{19}$. These are the following regulations: the regulation of the Minister of the Environment of 2 October 2007 on the requirements to conduct measurements of levels in the environment of substances or energy managing road, railway, tramway, airport, port ${ }^{20}$ and the regulation of the Minister of the Environment of 4 November 2008 on the requirements for carrying out measurements and measurements of emissions, quantity of water consumed ${ }^{21}$.

\section{Noise - emissions or environment pollution}

One of the objectives of environmental protection is taking care of the condition and quality of the environment. Therefore, the regulations of the EPA emphasize the issues of environmental protection from pollution. From this point of view the crucial terms used by the EPA are 'emission' and 'pollution'. The meaning of these terms is similar and the distinction between them is of high significance for the regulations related to the protection of environmental quality and establishment of the basis defining acceptability of actions consisting in introduction of substance and energy to the environment. The adopted principle by the Act is the assumption that an emission is a permitted action (legal), while pollution is also an emission, however it can be defined as a qualified emission, due to negative consequences, which should not occur, thus it is forbidden (illegal). As a consequence regulations concerning environmental protection from pollution define permissible emission levels always in a way to prevent 'emission' limits from becoming 'pollution'22.

19 J. Jerzmański, Komentarz do art. 112b u.p.o.ś., [w:]M. Górski, M. Pchałek, W. Radecki, J. Jerzmański, M. Bar, S. Urban, J. Jendrośka, Prawo ochrony środowiska. Komentarz, Warszawa 2011, p. 426-427.

20 Journal of Laws, No 192, item 1392.

21 Journal of Laws, No 206, item 1291.

22 M. Bar, M. Górski, J. Jerzmański, M. Pchałek, W. Radecki, Komentarz do art. 3 pkt 4 u.p.o.ś., [w:] M. Górski, M. Pchałek, W. Radecki, J. Jerzmański, M. Bar, S. Urban, J. Jendrośka, Prawo ochrony..., p. 54. 
Within the meaning of article 3 point 4 of the EPA, an emission consists in introduction into the environment components i.e. air, water, ground, soil, or agents such as substances and energy. The discharge can be direct or indirect and must be always a result of a human activity. The term substances refers to chemical elements and their compounds, mixtures and solutions present in the environment or formed as a result of human activities (article 3 point 36 of the EPA). Energies are listed as the examples, and include among others noise, vibrations, and electromagnetic fields.

Emissions as substances introduced to the environment or specified energy types, should be understood as a substance or energy in the particular component of the environment, not present previously or present in a lower amount. In such context an emission is always an 'added value' to the environment, added as a result of a human activity ${ }^{23}$.

Besides the definition of an 'emission' presented in the EPA, the second definition of 'emission' exists parallel in the Polish law, formulated in the Act of 13 April 2007 on the prevention and remedying of damage to the environment ${ }^{24}$. Article 6 point 5 lists the following emissions introduced as a result of a direct or indirect human activity: substances and their mixtures or solutions; energies such as noise, vibrations or electromagnetic fields; organisms or microorganisms. The term 'a substance' has been also specified. In the EPA in order to check what the legislator defines as 'a substance' it is necessary to check in the glossary of terms.

In the community legislation and the Polish legislation there are some discrepancies with regard to the definition of 'an emission'. The directive 2008/1/EC of the European Parliament and of the Council of 15 January 2008 , concerning integrated pollution prevention and control ${ }^{25}$ limits the term 'emission' to 'an emission for an installation'. According to the Directive the emission refers to a direct or indirect release of substance, vibration, heat and noise from point sources or diffused sources in an installation, into the air, water environment or soil. In this approach 'an emission' refers only to the introduction to the environment substances and energies coming from industrial activities; and not as it is in the case of the Polish law - from any human activity.

23 Ibidem, p. 55

24 Journal of Laws, No 75, item 493.

25 OJ [2008] L Nr 24. 


\section{Anna Pieniak}

'Pollution' is the second important term in the field of environmental protection from noise. As it had already been mentioned the term 'pollution' refers to a qualified emission. Due to the caused effect it is negatively assessed, thus its occurrence is unwanted.

According to the definition given in the Act, 'pollution' is an emission, which can be harmful to human health or environment conditions, it causes damages to material goods, deteriorates aesthetics of the environment or interferes with other justified methods of environmental use (article 3 point 49 of the EPA).

The Polish definition is consistent with the guidelines included in the European law. It is correct to say that the term 'pollution' implemented into the Polish legislation is consistent with the guidelines for defining 'pollution' in the Directive 2008/1/WE. According to article 2 point 2 'pollution' is a direct or indirect introduction, as a result of a human activity, of substances, vibrations, heat or noise into the air, water or land which may be harmful to human health or the quality of the environment, result in damage to material property, or impair or interfere with amenities and other legitimate uses of the environment.

According to the EPA the protection from noise (including preventing pollution) consists mainly in preventing (limiting) introduction of mentioned above substances and energy ${ }^{26}$. Regulations in this scope base on the control of discharge of gases and dusts into the atmosphere, discharge of wastewater or wastes into water and ground, noise generation or electromagnetic fields.

The prevention from emissions should be performed by the determination of the required standards of environmental quality, control their adherence, undertaking the actions aiming at maintaining the standards (restoration), and first of all by the reduction of emissions ${ }^{27}$. According to M. Gorski ${ }^{28}$ the above assumptions are based on a two-way protection approach. Firstly, it specifies the requirements with regard to the quality of natural resources, together with undertaking actions aiming at the restoration of infringed requirements. Secondly, it is based on the simultaneous actions aiming

26 A. Lipiński, Prawne podstawy ochrony środowiska, Kraków 2007, p. 231.

27 A. Lipiński, Ochrona przed hatasem - znowelizowane prawo ochrony środowiska, Bezpieczeństwo Pracy 2005, No 7-8, p. 10 -14.

28 M. Górski, Ochrona jakości środowiska i prawo emisyjne, [w:]M. Górski (red.), Prawo ochrony środowiska, Bydgoszcz 2006, 189. 
at maintaining indicated requirements, especially by limiting and controlling the introduction of substances and energy into these resources.

Environmental quality standards in article 3 point 34 of the EPA are defined as acceptable levels of substances or energy that must be achieved in a given time by the environment as a whole or its natural components.

It should be stressed that emission standards and emission limit values are both a measure specifying permissible emissions. The difference consists in the fact that emission standards are general standards determining allowable emission by means of a regulation. Whereas, emission limit values are specific and established for a particular installation in a permit ${ }^{29}$. Environmental quality standards with regards to noise emission are determined in the Regulation of the Minister of the Environment of 14June 2007.

While determining environmental quality standards two groups of factors should be taken into account. First of all, the type of an impact of substances or energy on the environment should be considered, and afterwards, the scale of this impact. In practice the standards established for the parameters most important from human and environmental point of view, as a kind of 'minimum quality program', considering also current economic and technical conditions. Therefore, in the quality standards definition it is indicated that the levels are established for a specified period, which can be interpreted that these levels can be changed in the future, when reaching most strict levels is possible ${ }^{30}$.

Emission values have also been defined in article 3 point 43 of the EPA. According to the above mentioned article, an emission value is the type and number of introduced substances or energy in a specified period and concentrations or levels of substances or energy, especially in exhaust gases, discharged wastewater and generated wastes. This term is quite often used in the EPA, especially in the context of obligations with regards to the reduction or emissions measurements. It covers not only emission values in the physical sense (the amount of introduced substances or energy), but also determination of the type of $\mathrm{it}^{31}$. Additionally it is indicated in the definition that during the establishment of emission values, such factors

29 J. Stelmasiak (red.), Prawo ochrony...., p.231.

30 M. Górski (red.), Prawo ochrony środowiska, Warszawa 2009, p. 209.

31 J. Jendrośka, M. Bar, Prawo ochrony..., p. 708-709. 


\section{Anna Pieniak}

as emission duration time of substances or energy to the environment should be taken into account, as well as their concentrations and levels.

According to Marek Górski ${ }^{32}$ the effect of introducing the term 'emission value' to the environmental protection act is the obligation of emission measurements, which consists in the measuring of all parameters indicated in the definition (except for the situation, when this obligation was specified individually).

Environmental protection against pollution is included in the title III 'Pollution prevention' of the EPA, in which general provisions related to the protection of all environment components, as well as more detailed regulations including protection in the sector context are given.

Regulations regarding protection against pollution can be divided into two main groups: the ones applying to pollutants coming from specified sources, such as: installations and devices; substances and products; socalled diffused sources - roads, railways, trams, airports and ports, power grids; specifying basic material and procedural requirements for issuing permits for discharge of substances and energy to the environment ${ }^{33}$.

Regulations concerning protection against pollution, as well as against noise, including noise emissions, should be developed in a way to maintain specified quality requirements for particular environmental compounds. Moreover, according to $\mathrm{M}$. Gorski ${ }^{34}$ both directions of protective actions determine and complement each other, thus they should be undertaken in parallel. The interpretation of environment protection regulations against noise should be carried out with consideration of the needs for achieving the objectives of the quality protection and general objectives of the environmental protection by means of these regulations.

32 M. Górski, Komentarz do art. 3 pkt 43 u.p.o.ś., [w:]J. Jendrośka (red.), Ustawa prawo..., p. 86.

33 M. Górski, Ochrona jakości środowiska..., p. 192.

34 M. Górski, Wprowadzenie do tytułu III. Przeciwdziałanie zanieczyszczeniom, [w:] M. Górski, M. Pchałek, W. Radecki, J. Jerzmański, M. Bar, S. Urban, J. Jendrośka, Prawo ochrony........., p. 604. 


\section{Literature}

1. A. Lipiński, Prawne podstawy ochrony środowiska, Kraków 2007

2. A. Lipiński, Ochrona przed hatasem - znowelizowane prawo ochrony środowiska, Bezpieczeństwo Pracy 2005, No 7-8.

3. B. Rakoczy, M. Pchałek (red.), Wybrane problemy prawa ochrony środowiska, Warszawa 2010.

4. H. Kujawa-Łobaczewska,J. Goszczyński (red:), Klimat akustyczny województwa kujawsko-pomorskiego w badaniach WIOŚ, Bydgoszcz 2004.

5. J. Jendrośka, M. Bar, Prawo ochrony środowiska, podręcznik. Wrocław 2005.

6. J. M. Massalski, J. Stadnicki, Legalne jednostki miar i state fizyczne, Warszawa 1999.

7. J. Stelmasiak (red.), Prawo ochrony środowiska, Warszawa 2009.

8. K. Dworak, Hatas środowiskowy a zdrowie, Wojewódzka Stacja Sanitarno-Epidemiologiczna w Katowicach, Katowice 2005.

9. M. Górski (red.), Prawo ochrony środowiska, Bydgoszcz 2006.

10. M. Górski, M. Pchałek, W. Radecki, J. Jerzmański, M. Bar, S. Urban, J. Jendrośka, Prawo ochrony środowiska. Komentarz, Warszawa 2011.

11. Z. Engel, Ochrona środowiska przed drganiami i hatasem, Warszawa 2001.

12. Z. Engel,W.M.Zawieska, Ochrona przed hatasem w środowisku-stan zagadnienia w roku przystapienia do Unii Europejskiej, Bezpieczeństwo Pracy 5/2004.

\section{European Union regulations}

1. Directive 2002/49/EC of the European Parliament and of the Council of 25 June 2002 relating to the assessment and management of environmental noise, OJ [2002] L 189/12.

2. Directive $98 / 37 / \mathrm{EC}$ of the European Parliament and of the Council of 22 June 1998 on the approximation of the laws of the Member States relating to machinery, OJ [1998] L 207.

3. Directive 2008/1/EC of the European Parliament and of the Council of 15 January 2008, concerning integrated pollution prevention and control, OJ [2008] L No 24.

4. Directive 2000/14/EC of the European Parliament and of the Council of 8 May 2000 on the approximation of the laws of the Member States relating to the noise emission in the environment by equipment for use outdoors, OJ [2000] L 162.

5. Directive 2003/10/EC of the European Parliament and of the Council of 6 February 2003 on the minimum health and safety requirements regarding 


\section{Anna Pieniak}

the exposure of workers to the risks arising from physical agents (noise), OJ [2003] L 42.

\section{National regulations}

1. Environment Protection Act of 27 of June 2001, Journal of Laws of 2008, No 25, item 150 with amendments.

2. Revision of Environment Protection Act of 18 May 2005, Journal of Laws, No 113 , item 954.

3. Act of 13 April 2007 on the prevention and remedying of damage to the environment, Journal of Laws, No 75, item 493.

4. Regulation of Minister of Environment of 2 of October 2007 on the requirements to conduct measurements of the levels in the environment of substances or energy managing the road, railway, tramway, airport, port, Journal of Laws, No 192, item 1392.

5. Decree of Minister of Environment of 4 November 2008 on the requirements for carrying out measurements and measurements of emissions, quantity of water consumed, Journal of Laws, No 206, item 1291.

6. Decree of Minister of Environment of 10 November 2010 on the establishment of the noise indicator LDWN, Journal of Laws, No 215, item 1414.

7. Decree of Minister of Environment of 14 June 2007 on permissible levels of noise in the environment, Journal of Laws, No 120, item 826. 